\title{
Response of Soil Carbon and Nitrogen to 15-year Experimental Warming in Two Alpine Habitats (Kobresia Meadow and Potentilla Shrubland) on the Qinghai-Tibetan Plateau
}

\author{
Dongdong Chen', Liang Zhao ${ }^{1}$, Qi Li', Hai Cai', Jingmei Li ${ }^{3}$, \\ Shixiao $\mathrm{Xu}^{1}$, Xinquan $\mathrm{Zhao}^{1 *}$
}

${ }^{1}$ Key Laboratory of Adaptation and Evolution of Plateau Biota, Haibei Alpine Meadow Ecosystem Research Station, Northwest Institute of Plateau Biology, Chinese Academy of Sciences, Xining 810008, PR China ${ }^{2}$ Department of Agricultural Economics, Wuwei Occupational College, Wuwei 733000, PR China ${ }^{3}$ Qinghai Academy of Social Sciences, Xining 810001, PR China

Received: 20 June 2016

Accepted: 20 July 2016

\begin{abstract}
Although the Qinghai-Tibetan Plateau (QTP) has experienced striking warming during the past century, information on how soil carbon (C) and nitrogen (N) pools of the alpine regions on the QTP respond to long-term warming is scarce. The aims of this study were to assess the response of soil organic C (SOC), total $\mathrm{N}(\mathrm{TN})$, labile $\mathrm{C}$ and $\mathrm{N}$ - including microbial biomass $\mathrm{C}(\mathrm{MBC})$ and $\mathrm{N}(\mathrm{MBN})$, inorganic $\mathrm{N}\left(\mathrm{N}_{\text {inorg }}\right)$, dissolved organic $\mathrm{C}(\mathrm{DOC})$, and $\mathrm{N}(\mathrm{DON})$ - to 15-year experimental warming in an alpine region (Kobresia meadow and Potentilla scrubland), on the northeastern QTP using open-top chambers (OTCs). Fifteen-year experimental warming had no effect on SOC and TN concentrations and storage at 0-30 cm soil depth, either in Kobresia meadow or Potentilla scrubland habitat, which might be related to the low temperature increase and the unchanged water content. Long-term warming obviously affected soil labile $\mathrm{C}$ and $\mathrm{N}$ and their contributions to SOC and TN, especially in the meadow habitat, but the values were low, thus the variation of the labile $\mathrm{C}$ and $\mathrm{N}$ was not enough to influence total $\mathrm{C}$ and $\mathrm{N}$ storage. The $\mathrm{C}$ and $\mathrm{N}$ pools were shown to be controlled by different controlling factors, and scrubland was more stable than the meadow ecosystem confronting the change of environment.
\end{abstract}

Keywords: Qinghai-Tibetan Plateau, experimental warming, soil dissolved organic carbon, microbial biomass carbon, alpine region

*e-mail: xqzhao@nwipb.cas.cn 


\section{Introduction}

The IPCC has predicted that global mean surface temperature could increase by $1.0-3.7^{\circ} \mathrm{C}$ by the end of this century. Global warming could stimulate carbon (C) sequestrations in soil [1-2], therefore, with the context of climatic warming, understanding the effects of changes in temperature on soil $\mathrm{C}$ and nitrogen $(\mathrm{N})$ in terrestrial ecosystems is vital to global $\mathrm{C}$ and $\mathrm{N}$ cycling [3-4]. In the past decades, inconsistent results on the responses of soil $\mathrm{C}$ and $\mathrm{N}$ pools to climatic warming have been observed [5-7]. Some research has demonstrated that warming can have pronounced effects on soil $\mathrm{C}$ and $\mathrm{N}$ [8-9], while some concluded that warming had no significant effect [10-12]. These findings indicate that there are a great many uncertainties in the response of soil $\mathrm{C}$ and $\mathrm{N}$ to warming, and that clarifying the effect of warming on soils needs to consider ecosystem types, initial soil characteristics, their local climate, and the years of warming $[10,13]$.

The Qinghai-Tibetan Plateau (QTP) is one of the most sensitive areas to respond to global climate change. The annual mean ground surface temperature increase over the QTP during the period of $1980-2007$ was about $0.60^{\circ} \mathrm{C} /$ decade, which was more pronounced than the increase of mean annual air temperature on the plateau [14]. Simulation experiments have been carried out in this area to examine the impacts of experimental warming on soil $\mathrm{C}$ and $\mathrm{N}$ dynamics [1, 6, 11-12, 15] and soil microbial community [16]. Some of this research has shown that warming can have pronounced effects on soil nutrients [9], and microbial community structure and activity [16-17], while others have shown that warming had no obvious effect on soil nutrients [11-12]. Klein et al. [1820] and Wang et al. [21] observed the impacts of shortterm warming on microclimate, plant species diversity, and primary productivity of alpine meadow (Kobresia meadow and Potentilla scrubland) on the QTP. However, the time of warming of the above research was less than 10 years, and information on how soil $\mathrm{C}$ and $\mathrm{N}$ of the alpine meadow on the QTP will respond to long-term (>10-year) warming is scarce.

Both water and temperature are the main factors in litter decomposition, transformation of organic matters, immobilization of inorganic $\mathrm{C}$ and $\mathrm{N}$, and the associated processes mediated by microbes $[1,11]$. The increase of the global mean surface temperature predicted by IPCC [22] is far below the daily range of temperature in QTP (which can reach $13-23^{\circ} \mathrm{C}$ ) [23], thus the fundamental temperature ranges of soil microbial communities may be sufficiently broad to buffer their functioning against changes in global climate [24]. Meanwhile, in our research site, soil moisture remained at a relatively high level $(>30 \%)$, suggesting that soil water might not act as a limiting factor to below-ground ecological processes in this region [9]. Based on this evidence, we hypothesized that long-term warming had no effect on the soil $\mathrm{C}$ and $\mathrm{N}$ pools due to the lower warming magnitude and the relatively high soil water content. Our objective was to assess the response of SOC, TN, MBC, MBN, DOC, DON, and $\mathrm{N}_{\text {inorg }}$ to 15 -year experimental warming in two alpine habitats (Kobresia meadow and Potentilla scrubland) on the QTP.

\section{Materials and Methods}

\section{Description of the Study Sites}

We conducted our research at the Haibei Alpine Ecosystem Research Station (HAERS), a facility run by the Northwest Plateau Institute of Biology, Chinese Academy of Sciences. The research site is situated at $37^{\circ} 36^{\prime} \mathrm{N}$, $101^{\circ} 18^{\prime} \mathrm{E}$, with a mean annual temperature of $-1.7^{\circ} \mathrm{C}$, and a mean annual precipitation of $600 \mathrm{~mm}$ - more than $80 \%$ of which falls during the summer monsoon season. The mean elevation of the valley bottom is 3,200 $\mathrm{m}$ [25]. There are two main habitats in the region: winter-grazed meadow situated along the valley floor, and summergrazed scrubland located on the higher slopes encircling the valleys. The meadow is dominated by an assemblage of graminoids including Kobresia; the scrubland is dominated by a deciduous shrub, Potentilla fruticosa. Forbs, grasses, and sedges occur at all sites; however, the specific vegetative assemblages depend on habitat and grazing history. The alpine meadow and shrub vegetation that occur in this region comprise approximately 35\% of the QTP area [26]. Plots of $75 \times 75 \mathrm{~cm}$ have 30 plant species on average, with most plants $\mathrm{C}_{3}$ and $87 \%$ perennial [27]. Roots are mainly concentrated in the topsoil layer $(0-20 \mathrm{~cm})$ [15]. Mean air temperature and total rainfall during growing seasons from 1 May to 30 September in 2012 and 2013 were 8.2 and $8.72^{\circ} \mathrm{C}$, and 352.4 and $404.1 \mathrm{~mm}$, respectively. Total rainfall and air temperature in 2012 and 2013 are shown in Fig. 1.

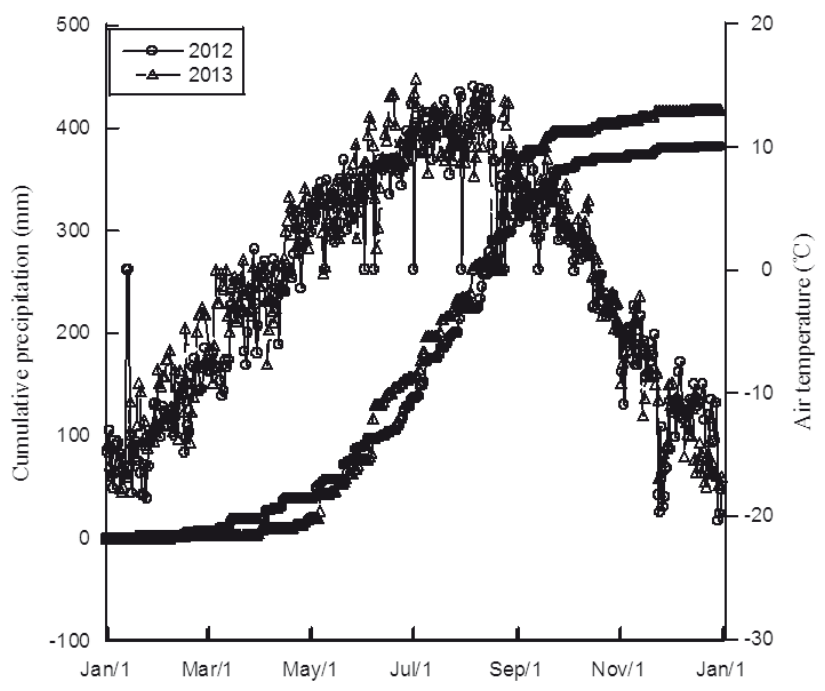

Fig. 1. Air temperature and total precipitation of the research site (in 2012 and 2013). 


\section{Experimental Design and Soil Sampling}

The simulated warming experiment in both the Kobresia meadow and Potentilla scrubland habitats began in 1997. In each habitat, a $30 \times 30 \mathrm{~m}$ block was fenced, within which 16 plots were arranged in a $4 \times 4$ matrix, and eight sites were chosen randomly to simulate warming using fiberglass open top chambers (OTCs), and the rest left as controls (CK). The OTCs, which were $1.5 \mathrm{~m}$ diameter and $40 \mathrm{~cm}$ high, were constructed of Sun-Lite HP (Solar Components Corporation, Manchester, NH, USA) $1.0 \mathrm{~mm}$ thick fiberglass and remained on the plots year-round [18]. OTC experiments simulated warming following the method of Norby et al. [28]. There were about $2 \mathrm{~m}$ between each plot. We sampled soils in OTCs as "M-OTC" in meadow and "S-OTC" in scrubland, and in control (no-warming) plots as "M-CK" in meadow and "S-CK" in scrubland, so that four treatments were present (two treatments in each habitat). Previous studies have shown that there was still a temperature change between OTCs and CK in alpine meadow after a more than 10 -year experimental warming, and OTCs increased soil temperature by $0.8-1.1^{\circ} \mathrm{C}$ at $0-15 \mathrm{~cm}$ in the alpine meadow [12].

Soil samples (at depths of 0-10, 10-20, and 20-30 cm) were collected in August 2012 and 2013 at each site. In each plot, the soil cores $(5 \mathrm{~cm}$ diameter) were collected from three random points, and mixed into one sample in each layer. All soil samples were sent to the laboratory and sieved through a $2 \mathrm{~mm}$ sieve and stored in a refrigerator at $4^{\circ} \mathrm{C}$ prior to analyses. Subsamples of the fresh soil were used to measure MBC, MBN, DOC, DON, $\mathrm{N}_{\text {inorg, }}$, and other subsamples of the fresh soil were air-dried for measurements of SOC and TN.

\section{Soil Carbon and Nitrogen Analysis}

Soil microbial biomass C (MBC) and N (MBN) were determined using the chloroform fumigation-extraction method [29-30]. Briefly, the fumigated and non-fumigated samples (10 g dry weight equivalent) were extracted with $50 \mathrm{ml}$ of $0.5 \mathrm{M} \mathrm{K}_{2} \mathrm{SO}_{4}$ for $30 \mathrm{~min}$ on a shaker. The extracts were filtered through $0.45 \mu \mathrm{m}$ filters and determined for extracted $\mathrm{C}$ by potassium dichromate-vitriol oxidation method and $\mathrm{N}$ by Kjeldahl digestion [31]. MBC and MBN were calculated from the differences between extracted $\mathrm{C}$ and $\mathrm{N}$ contents in the fumigated and non-fumigated samples using conversion factors of 0.38 and 0.45 [29-30], respectively. And the extracted $\mathrm{C}$ and $\mathrm{N}$ in nonfumigated samples were considered as soil dissolved organic $\mathrm{C}$ (DOC) and total dissolved organic N (TDN) [32]. Soil $\mathrm{N}_{\text {inorg }}$ were determined in $2 \mathrm{M} \mathrm{KCl}$ extracts by a Skalar San++ continuous flow analyzer while DON was calculated as the difference between TDN and $\mathrm{N}_{\text {inorg }}$ [1].

According to the methods described by Lu [31], SOC content $\left(\mathrm{g} \mathrm{kg}^{-1}\right)$ of the samples was measured using the potassium dichromate-vitriol oxidation method. For this procedure, $0.1000 \mathrm{~g}$ of soil sample was digested with
$5 \mathrm{ml}\left(0.8 \mathrm{~mol} \mathrm{~L}^{-1}\right) \mathrm{K}_{2} \mathrm{Cr}_{2} \mathrm{O}_{7}$ and $5 \mathrm{ml}$ concentrated $\mathrm{H}_{2} \mathrm{SO}_{4}$ at $180^{\circ} \mathrm{C}$ for $5 \mathrm{~min}$, followed by titration of the digests with standardized $\mathrm{FeSO}_{4}$. Soil $\mathrm{TN}\left(\mathrm{g} \mathrm{kg}^{-1}\right)$ was analyzed using the micro-Kjeldahl method. Soil $\mathrm{pH}$ was determined in 1:2.5 (w/v) soil/ $\mathrm{KCl}$ extracts using a combination glass electrode, and soil gravimetric moisture was determined by drying at $105^{\circ} \mathrm{C}$ for $24 \mathrm{~h}$.

$$
\begin{aligned}
& \text { SOC storage }\left(\mathrm{kg} \mathrm{m}^{-2}\right)=\sum_{i=1}^{n} D_{i} \times B_{i} \times C_{i} \times 10^{4} / 10^{3} \\
& T N \text { storage }\left(\mathrm{kg} \mathrm{m}^{-2}\right)=\sum_{i=1}^{n} D_{i} \times B_{i} \times C_{i} \times 10^{4} / 10^{3}
\end{aligned}
$$

...where $D_{i}$ is soil layer thickness (m), $B_{i}$ is soil bulk density $\left(\mathrm{kg} \mathrm{m}^{-3}\right)$, and $C_{i}$ is the SOC or TN concentration $\left(\mathrm{g} \mathrm{kg}^{-1}\right)$. Soil bulk density was calculated as the mass of the oven-dried soil $\left(105^{\circ} \mathrm{C}\right)$ divided by the core volume using $3.8 \mathrm{~cm}$ diameter and $10 \mathrm{~cm}$ height.

\section{Data Analysis}

The statistical evaluation was done using SPSS for Windows version 16.0 (SPSS Inc., Chicago, IL). All results were reported as a mean on a dry soil basis. Oneway ANOVA was used to test the statistical significance of the SOC and TN storage, soil moisture, SOC, TN, MBC, MBN, DOC, DON, and $\mathrm{N}_{\text {inorg }}$ concentrations, and the proportions of $\mathrm{MBC}$ and DOC in SOC storage (MBC/SOC (\%) and DOC/SOC (\%)), and MBN, DON, and $\mathrm{N}_{\text {inorg }}$ in TN storage (MBN/TN (\%), DON/TN (\%) and $\mathrm{N}_{\text {inorg }}$ /TN (\%)) between the treatments at the same soil depth separately in 2012 and 2013. All data were tested for homogeneity of variances using LSD before further analysis, and natural logarithm transformations were made if necessary. The level of significance was $P<0.05$. Values in the text and figures are means \pm standard error (SE).

We evaluated the relationships among soil properties by performing principal component analysis (PCA), which was computed using the "vegan" library (Oksanen et al., 2015. version 2.2-1; http://cran.r-project.org/package = vegan) of the R statistical language ( $\mathrm{R}$ Core Team, 2015. version 3.2.0, Vienna, Austria; www.r-project.org).

\section{Results}

Results of PCA showed the relationships between soil properties in Fig. 2. With the results of the three layers together, the PCA1 and PCA2 explained 36.29\% and $11.30 \%$ of the variances of the data, respectively. Soil physiochemical properties showed high correlation coefficients for PCA1, and soil microbial properties for PCA2. The Potentilla scrubland had a clear separation from the Kobresia meadow with higher ordinate scores on PCA1, while the warming plots clearly differed from 
Table 1. Comparison of soil water content (\%) and soil $\mathrm{pH}$ at $0-10,10-20$, and 20-30 $\mathrm{cm}$ soil depths between warmed and unwarmed plots in the Kobresia meadow and Potentilla shrubland (August 2012 and 2013).

\begin{tabular}{|c|c|c|c|c|c|c|c|c|c|}
\hline \multicolumn{2}{|c|}{} & \multicolumn{4}{|c|}{2012} & \multicolumn{4}{c|}{2013} \\
\cline { 3 - 10 } \multicolumn{2}{|c|}{} & M-OTC & M-CK & S-OTC & S-CK & M-OTC & M-CK & S-OTC & S-CK \\
\hline \multirow{4}{*}{$\begin{array}{c}\text { Water (\%) } \\
\end{array}$} & $0-10 \mathrm{~cm}$ & $43.92(0.82)$ & $50.07(0.99)$ & $62.39(2.09)$ & $65.41(2.70)$ & $47.91(1.40)$ & $53.96(2.56)$ & $61.21(1.88)$ & $63.74(1.97)$ \\
\cline { 2 - 10 } & $10-20 \mathrm{~cm}$ & $31.21(0.33)$ & $32.61(0.53)$ & $46.61(1.09)$ & $46.56(1.10)$ & $33.61(0.78)$ & $32.79(0.36)$ & $46.60(0.86)$ & $47.46(1.14)$ \\
\cline { 2 - 10 } & $20-30 \mathrm{~cm}$ & $31.31(0.30)$ & $31.98(0.26)$ & $42.33(4.99)$ & $38.23(0.61)$ & $32.99(0.66)$ & $31.36(0.43)$ & $37.39(0.49)$ & $39.47(1.79)$ \\
\hline $\begin{array}{c}\mathrm{pH} \\
\text { (soil:KCl } \\
=1: 2.5)\end{array}$ & $0-10 \mathrm{~cm}$ & $7.33(0.02)$ & $7.33(0.02)$ & $6.17(0.03)$ & $6.26(0.05)$ & $7.23(0.02)$ & $7.16(0.04)$ & $6.13(0.05)$ & $6.04(0.05)$ \\
\cline { 2 - 10 } & $10-20 \mathrm{~cm}$ & $7.53(0.01)$ & $7.49(0.02)$ & $6.25(0.06)$ & $6.31(0.05)$ & $7.41(0.02)$ & $7.42(0.01)$ & $6.08(.04)$ & $6.03(0.04)$ \\
\hline
\end{tabular}

Values are means and standard error.

There was no significant difference between warmed and unwarmed plots at the same soil depth of the same habitat for the same indicator $(P<0.05, \mathrm{n}=8)$.

Kobresia meadow-M, Potentilla scrubland-S, OTC-experimental warming, CK-unwarmed.

the no-warming with higher ordinate scores on PCA2 in the Kobresia meadow, and also between sampling times for the same treatment (Fig. 2). There was difference in the soil $\mathrm{C}$ and $\mathrm{N}$ pools between the two habitats in their response to environmental change (Tables 2-3, Figs 2-3).

Compared with the unwarmed plots, experimental warming did not influence soil water content and $\mathrm{pH}$ in
Kobresia meadow and Potentilla scrubland habitats. Soil moisture in scrubland sites was higher than in meadow sites, and $\mathrm{pH}$ was the opposite (Table 1). The response of SOC and TN storage at $0-30 \mathrm{~cm}$ soil depth to experimental warming was not significant. Although there was no significant change for TN storage between 2012 and 2013, SOC storage in Kobresia meadow was higher in 2013 than in 2012 (Fig. 3).

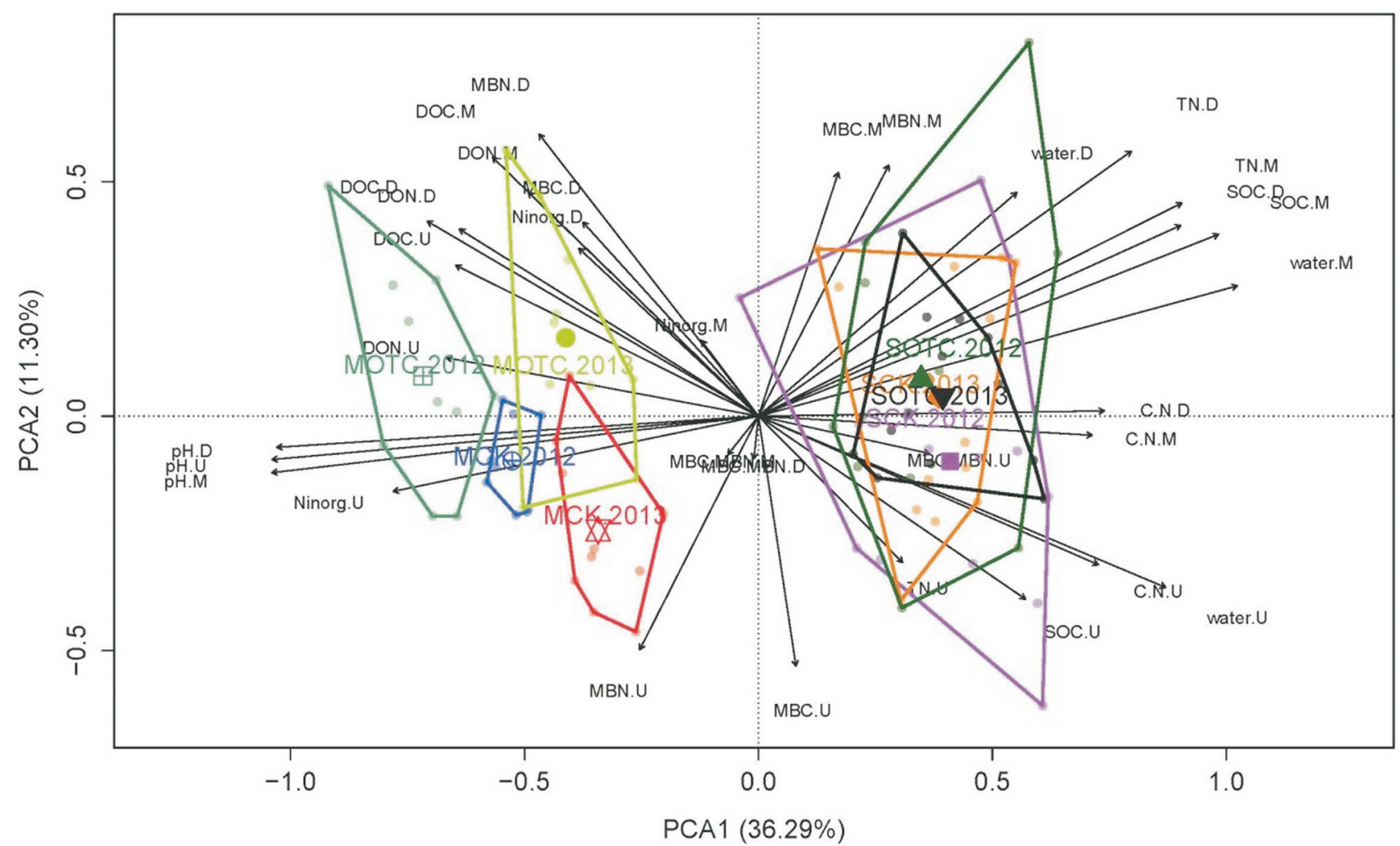

Fig. 2. Relationship between soil properties at 0-10, 10-20, and 20-30 cm soil depths at the two habitats in 2012 and 2013 , by performing principal components analysis (PCA).

SOC, soil organic C; TN, soil total N; MBC, soil microbial carbon; MBN, soil microbial nitrogen; DOC, dissolved organic C; DON, dissolved organic $\mathrm{N} ; \mathrm{N}_{\text {inorg }}$, soil inorganic $\mathrm{N} ; \mathrm{C} . \mathrm{N}$, soil C/N; MBC.MBN, microbial biomass C/N; water, soil water (\%); $\mathrm{pH}$, soil $\mathrm{pH}$; U, 0-10 cm soil depth; M, 10-20 cm soil depth; D, 20-30 cm soil depth (e.g. DOC.U, DOC.M, DOC.D); Đ, 2012 M-OTC; $\oplus, 2012$ M-CK; , 2013 M-OTC; 2013 M-CK; _, 2012 S-OTC; 12012 S-CK; V, 2013 S-OTC; , 2013 S-CK (M, Kobresia meadow; S, Potentilla scrubland; OTC, experimental warming; CK, no-warming). 


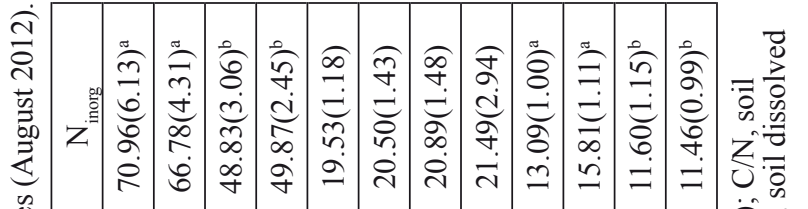

空

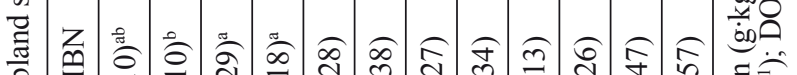

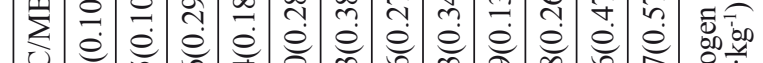

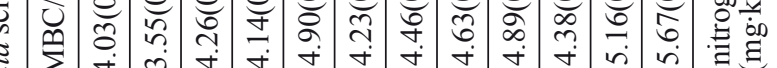

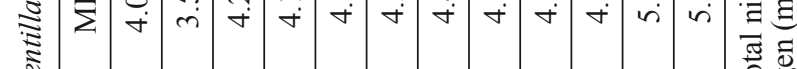

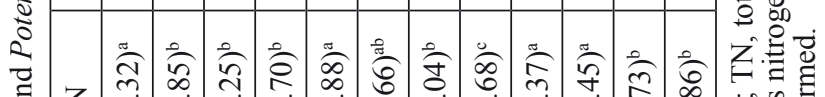

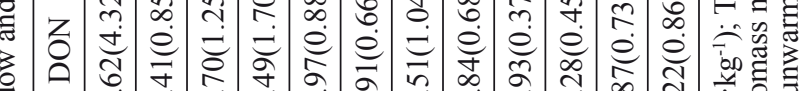
恖

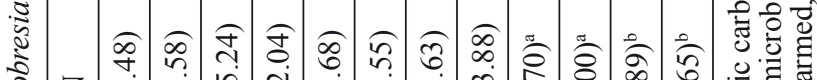

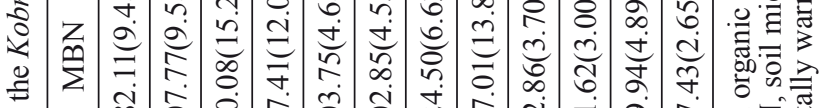
管

$\frac{n}{0}$

若

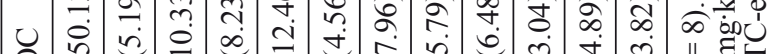
○

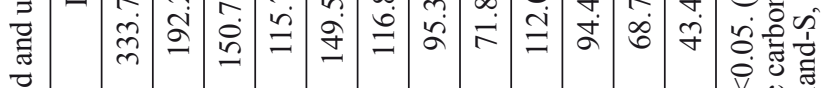

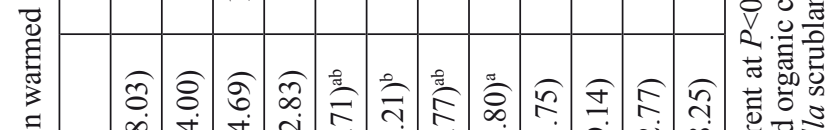

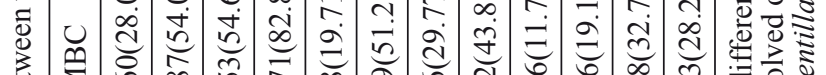

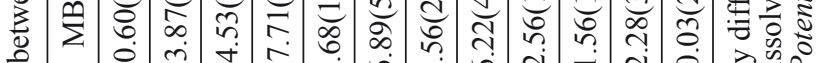

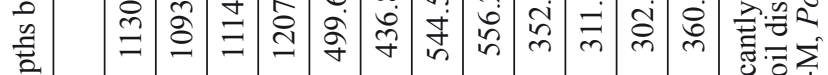

$\frac{8}{0}$

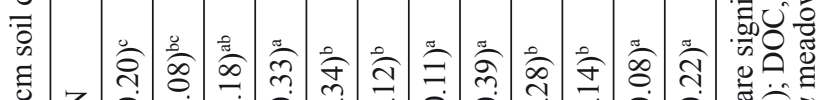

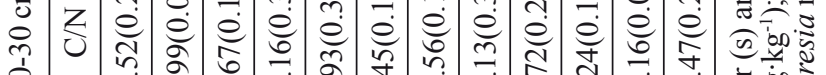

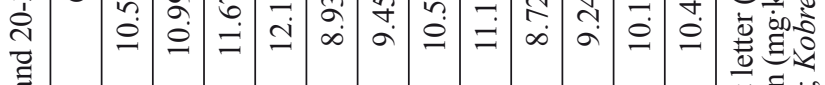

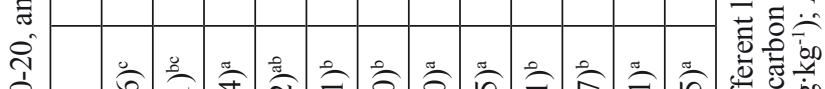

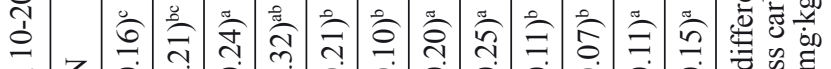

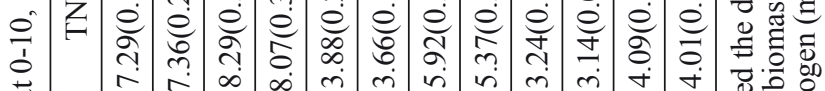

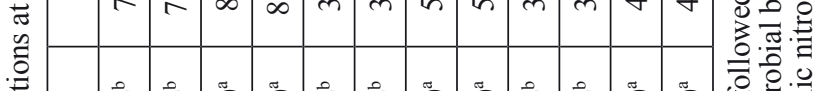

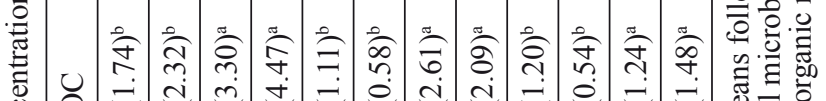

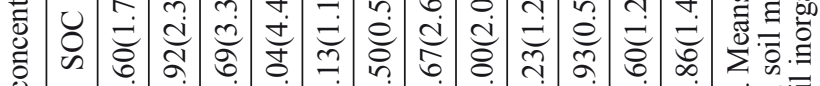
$z$

ग

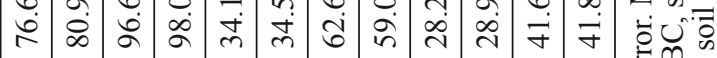

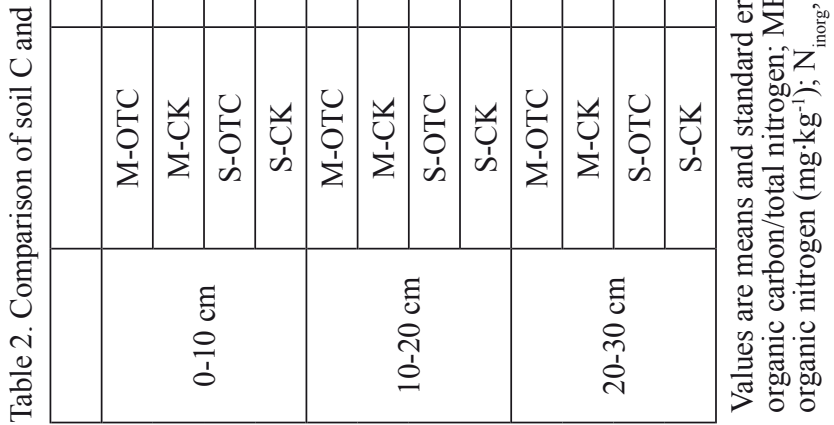

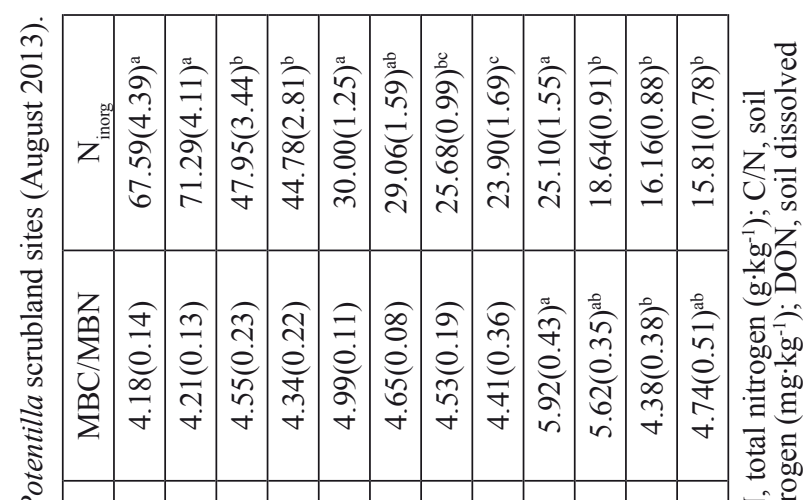

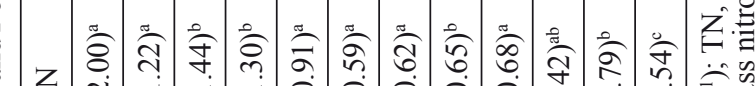

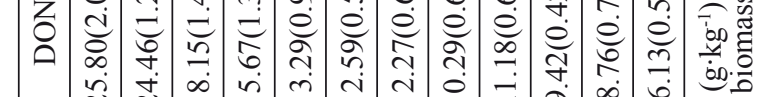

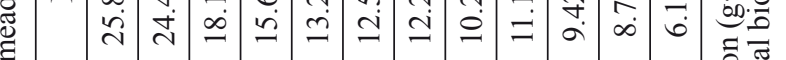

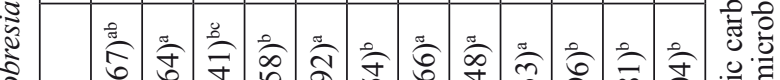

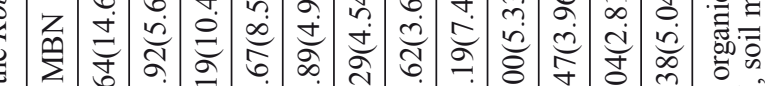

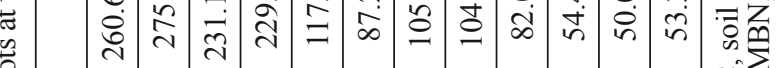

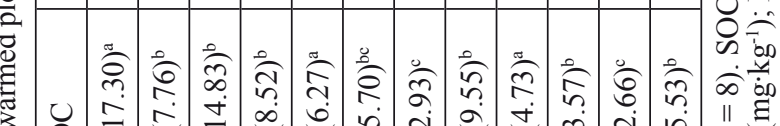

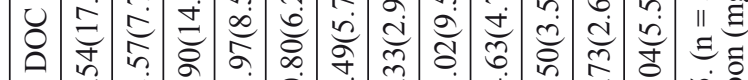
竎

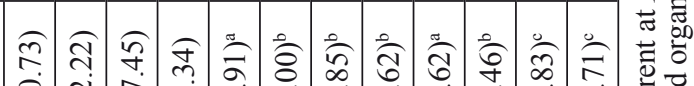

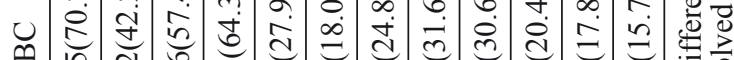

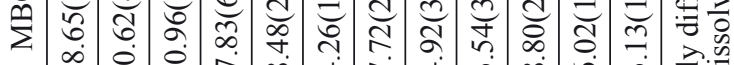

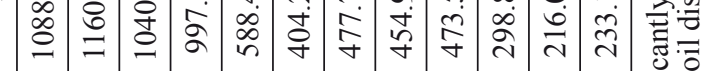

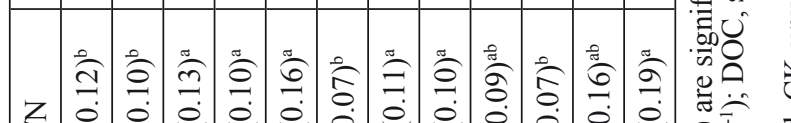

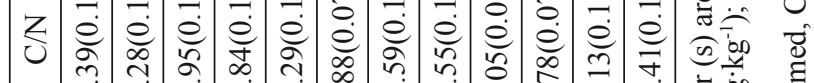

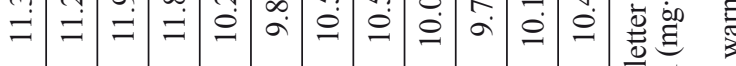

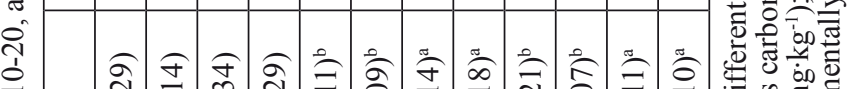

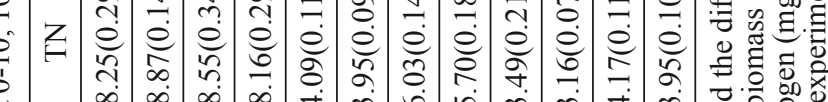

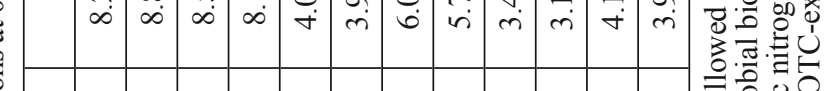

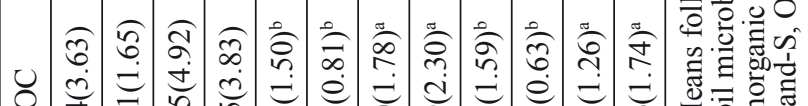

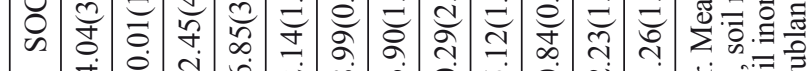

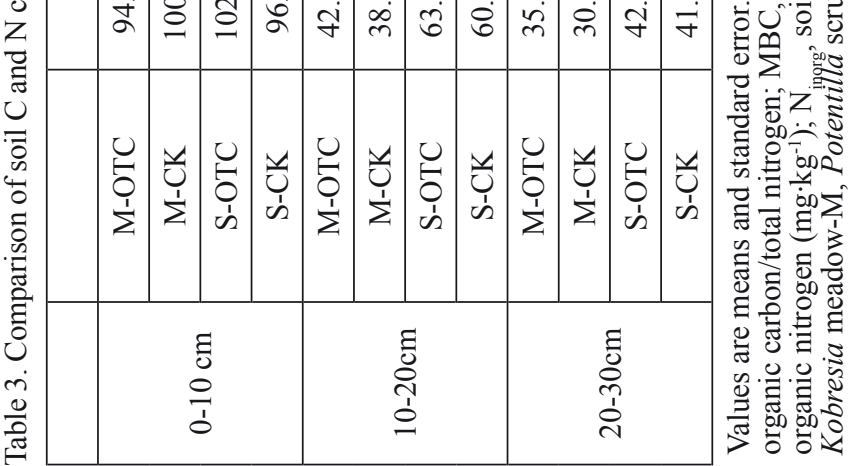




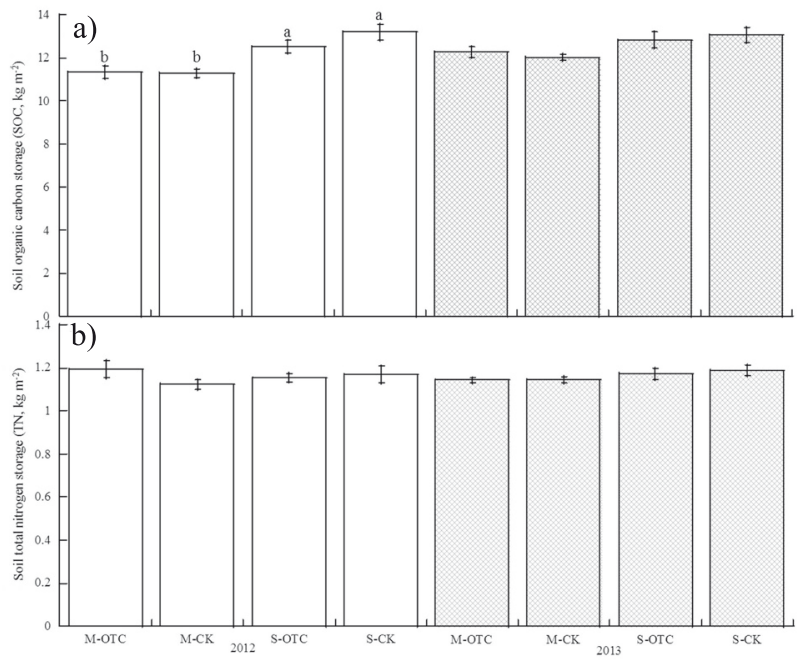

Fig. 3. Comparison of soil organic carbon (SOC) and total nitrogen (TN) storage $\left(\mathrm{kg} \mathrm{m}^{-2}\right)$ between warmed and unwarmed sites at 0-30 cm depth of Kobresia meadow and Potentilla scrubland habitats in 2012 and 2013 (Kobresia meadow, M; Potentilla scrubland, S; experimental warming, OTC; unwarmed, CK). Values are means and standard error. Means followed the different letter (s) are significantly different at $P<0.05$. $(\mathrm{n}=8)$.

In 2012, warming did not affect SOC, TN, MBC, $\mathrm{MBN}, \mathrm{N}_{\text {inorg }}, \mathrm{C} / \mathrm{N}$ ratio, or $\mathrm{MBC} / \mathrm{MBN}$ ratio either in Kobresia meadow or Potentilla scrubland. Warming significantly increased DOC, and had the tendency to raise DON in the two habitats, but the effect was not significant except at 0-10 cm soil depth in the meadow and 10-20 cm in the scrubland (Table 2). However, in 2013 experimental warming obviously increased the $\mathrm{DOC}, \mathrm{MBC}, \mathrm{MBN}$, and $\mathrm{N}_{\text {inorg }}$ in the meadow habitat - especially at 10-20 and 20-30 cm soil depths - and significantly decreased DOC and increased DON at 10-20 and 20-30 cm soil depths in the scrubland ecosystem, but did not affect SOC, TN, $\mathrm{MBC}, \mathrm{MBN}, \mathrm{N}_{\text {inorg }}$, or the $\mathrm{C} / \mathrm{N}$ ratio and $\mathrm{MBC} / \mathrm{MBN}$ ratio of scrubland (Table 3).

\section{Discussion}

Soil is one of the most important $\mathrm{C}$ and $\mathrm{N}$ pools and plays a crucial role in ecosystem $\mathrm{C}$ and $\mathrm{N}$ cycling [10], however, because of the large pool size, significant changes in soil $\mathrm{C}$ and $\mathrm{N}$ in response to climate change are usually difficult to detect in a short timeframe [33]. Our results showed that 15-year experimental warming had no effect on SOC and TN in Kobresia meadow and Potentilla scrubland, which may be related to lower warming magnitude $\left(0.8-1.1^{\circ} \mathrm{C}\right)$ and the unchanged soil water content. However the response of the labile $\mathrm{C}$ and $\mathrm{N}$ to experimental warming in two habitats was different.

The amount of SOC and TN represents the net balance between $\mathrm{C}$ and $\mathrm{N}$ inputs in the form of leaf, stem, and root litter, and $\mathrm{C}$ and $\mathrm{N}$ outputs including decomposition of $\mathrm{C}$ and $\mathrm{N}$ by soil microbes as well as $\mathrm{C}$ and $\mathrm{N}$ loss to downwind or downstream systems [4, 34]. Some researchers have demonstrated that warming increased soil $\mathrm{C}$ and $\mathrm{N}$, since warming causes a corresponding increase in vegetation productivity in the OTCs $[6,33,35]$, at least in the short term, and the increased productivity will probably increase litter production and the rhizosphere carbon inputs [36]. However, the degree to which this litter will accumulate or disappear, and thereby feed back to climate, will depend on the rate of decomposition [36]. Our results showed that warming had no obvious effect on SOC and TN, which are similar to Belay-Tedla et al. [10], Wang et al. [12] and Yu et al. [7]. First, we thought that the inputs were not affected by warming. Because although warming decreased total aboveground net primary productivity [20], grazing could mitigate the negative warming effects on rangeland quality [21], and grazing occurred in winter on our study sites. Research at the same study site showed that warming did not significantly affect plant species diversity [21], and plant diversity had a significant relationship with rhizosphere carbon inputs [37]. Second, warming did not affect the outputs by heterotrophic respiration, which was mediated by microbes, and was the dominant pathway of $\mathrm{C}$ and $\mathrm{N}$ loss [1-2]. Long-term warming might inhibit microbial capacity for decomposition of $\mathrm{C}_{3}$ litter [38], and as most plants on alpine meadow are $\mathrm{C}_{3}[1,27]$, the degradation of soil organic matter (SOM) in OTCs is probably inhibited. In addition, though warming increased microbial biomass in 2013, microbial communities with greater $\mathrm{C}$ - and $\mathrm{N}$-use efficiency might produce fewer degradative enzymes [39], and had no effect on soil total $\mathrm{C}$ and N. Research indicated that water availability regulated the response of soil respiration [40] and ecosystem $\mathrm{C}$ fluxes [41] to warming. In our research, we found that warming had no notable effect on soil water content either in Kobresia meadow and Potentilla scrubland (Table 1), which might be due to the unchanged vegetation cover and the accumulation of litter over many years [42], and soil C and N pools, especially SOC and TN had significantly positive relationship with soil water (Fig. 2). Therefore, more than a 10 -year experimental warming did not affect soil $\mathrm{C}$ and $\mathrm{N}$ storage due to the unchanged inputs and outputs of ecosystem $\mathrm{C}$ and $\mathrm{N}$ on the alpine meadow.

Warming significantly affected DOC and DON, and DOC was more sensitive than DON (Tables 2-3). Factors influencing DOC and DON are plant biomass input (which might include the standing death quality and belowground biomass) [10, 15], soil C/N ratio (9) and soil moisture [15], while our results showed that, except for the influence of temperature, DOC and DON were positively correlated with soil $\mathrm{pH}$ and negatively correlated with soil moisture and nutrients (Fig. 2). Yu et al. [7] indicated that soil $\mathrm{N}_{\text {inorg }}$ positively and significantly correlated with soil moisture and microbial biomass, which was not similar to our results. In our study, $\mathrm{N}_{\text {inorg }}$ was positively related to soil $\mathrm{pH}$ and labile $\mathrm{C}$ and $\mathrm{N}$ (DOC, DON, MBC, and MBN) while it had a negative relationship with soil moisture, SOC, and TN (Fig. 2). According to the correlation between the 
indicators, we anticipated that the variation of different $\mathrm{C}$ and $\mathrm{N}$ pools had different control factors, and the pools might be controlled by a combination of abiotic and biotic factors rather than a single factor.

Though warming influenced labile $\mathrm{C}$ and $\mathrm{N}$ (MBC, DOC, MBN, DON, and $\mathrm{N}_{\text {inorg }}$ ), the proportions of which in total SOC and $\mathrm{TN}$ storage were low $(\mathrm{MBC} / \mathrm{SOC}$ (\%), 0.79-1.43; DOC/SOC (\%), 0.11-0.43\%; MBN/TN (\%), 1.94-3.28\%; DON/TN (\%), 0.18-0.43\%; $\mathrm{N}_{\text {inorg }} / \mathrm{TN}$, $0.42-0.76 \%$ ), while the recalcitrant $\mathrm{C}$ and $\mathrm{N}$ pools contributed to a large amount of total $\mathrm{C}$ and $\mathrm{N}$ compared to labile $\mathrm{C}$ and $\mathrm{N}$ fractions [10], thus the variation of the labile $\mathrm{C}$ and $\mathrm{N}$ was not enough to influence total $\mathrm{C}$ and $\mathrm{N}$ storage.

For Kobresia meadow, the difference between treatments (warmed and unwarmed plots) at the same sampling time was caused by the variation of labile $\mathrm{C}$ and $\mathrm{N}$, while the difference between sampling times (2012 and 2013) for the same treatment was caused by the change of precipitation and temperature (in 2013, the air temperature and total rainfall were significantly higher and more than those in 2012). SOC and TN concentrations and SOC storage in Kobresia meadow in 2013 were higher than those in 2012 (Fig. 3, Tables 2-3), the possible reason might be that, beyond SOM itself, plant detritus (e.g., leaf litter, woody debris, dead roots) provides a major input of energy and nutrients for microbial decomposer communities [43-44], the higher temperature and greater rainfall in 2013 might stimulate the decomposition of plant detritus. Synthesizing all the indicators, experimental warming had no significant effect on Potentilla scrubland, which implied that scrubland was more stable than the meadow ecosystem under conditions of environmental change.

\section{Conclusion}

Our results support the hypothesis that 15-year experimental warming had no influence on SOC and TN, which might be related to the low temperature increase and the unchanged water content, while the labile pools of $\mathrm{C}$ and $\mathrm{N}$ in soil and their contribution to SOC and $\mathrm{TN}$ changed. The $\mathrm{C}$ and $\mathrm{N}$ pools were shown to be controlled by different controlling factors. There were also differences in the $\mathrm{C}$ and $\mathrm{N}$ pools in the habitats analyzed with the Potentilla scrubland being less influenced by warming than the Kobresia meadow.

\section{Acknowledgements}

This work was supported by the '13 th Five-Year' National Key Research and Development Program (No. 2016YFC0501805), the Chinese Academy of Sciences strategic project of science and technology (No. XDA05070200) the Qinghai Province Science and Technology Project (Nos. 2014-NS-112 and 2015-SF-A42), the National Key Technology Program of the Ministry of Science and Technology (Nos. 2012BAD13B01 and 2014BAC05B04). We also thank the meteorological station at HAERS for providing air temperature and precipitation data.

\section{References}

1. RUI Y.C., WANG S.P., XU Z.H., WANG Y.F., CHEN C.R., ZHOU X.Q., KANG X.M., LU S.B., HU Y.G., LIN Q.Y., LUO C.Y. Warming and grazing affect soil labile carbon and nitrogen pools differently in an alpine meadow of the Qinghai-Tibet Plateau in China. J. Soil. Sediment. 11, 903, 2011.

2. RUSTAD L.E., CAMPBELL J.L., MARION G.M., NORBY R.J., MITCHELL M.J., HARTLEY A.E., COMELISSEN J.H.C., GUREVITCH J., GCTE-NEWS. A meta-analysis of the response of soil respiration, net nitrogen mineralization, and aboveground plant growth to experimental ecosystem warming. Oecologia. 126, 543, 2001.

3. HE N.P., CHEN Q., HAN X., YU G., LI L. Warming and increased precipitation individually influence soil carbon sequestration of Inner Mongolian grasslands, China. Agr. Ecosyst. Environ. 158, 184, 2012.

4. SONG B., NIU S.L., ZHANG Z., YANG H.J., LI L.H., WAN S.Q. Light and heavy fractions of soil organic matter in response to climate warming and increased precipitation in a temperate steppe. Plos One. 7 (3), 1, 2012.

5. LI N., WANG G.X., GAO Y.H., WANG J.F. Warming effects on plant growth, soil nutrients, microbial biomass and soil enzymes activities of two alpine meadows in Tibetan Plateau. Pol. J. Ecol. 59 (1), 25, 2011a.

6. LI N., WANG G.X., YANG Y., GAO Y.H., LIU G.S. Plant production, and carbon and nitrogen source pools, are strongly intensified by experimental warming in alpine ecosystems in the Qinghai-Tibet Plateau. Soil Biol. Biochem. 43 (5), 942, 2011b.

7. YU C.Q., SHEN Z.X., ZHANG X.Z., SUN W., FU G. Response of soil $\mathrm{C}$ and $\mathrm{N}$, dissolvedorganic $\mathrm{C}$ and $\mathrm{N}$, and inorganic $\mathrm{N}$ to short-term experimental warming in an alpine meadow on the Tibetan Plateau. The Scientific World J. 2014, 152576, 2014.

8. LI N., WANG G.X., GAO Y.H., WANG J.F., LIU L.A. Effects of simulated warming on soil nutrients and biological characteristics of alpine meadow soil in the headwaters region of the Yangze River. Acta Pedologica Sinica. 47 (6), $1214,2010$.

9. XU Z.F., HU R., XIONG P., WAN C., CAO G., LIU Q. Initial soil responses to experimental warming in two contrasting forest ecosystems, Eastern Tibetan Plateau, China: Nutrient availabilities, microbial properties and enzyme activities. Appl. Soil Ecol. 46, 291, 2010.

10. BELAY-TEDLA A., ZHOU X.H., SU B., WANG S.Q., LUO Y.Q. Labile, recalcitrant, and microbial carbon and nitrogen pools of a tallgrass prairie soil in the US Great Plains subjected to experimental warming and clipping. Soil Biol. Biochem. 41, 110, 2009.

11. FU G., SHEN Z.X., ZHANG X.Z., ZHOU Y.T. Response of soil microbial biomass to short-term experimental warming in alpine meadow on the Tibetan Plateau. Appl. Soil Ecol. 61, 158, 2012.

12. WANG X.X., DONG S.K., GAO Q.Z., ZHOU H.K., LIU S.L., SU X.K., LI Y.Y. Effects of short-term and long-term warming on soil nutrients, microbial biomass and enzyme activities in an alpine meadow on the Qinghai- 
Tibet Plateau of China. Soil Biol. Biochem. 76 (9), 140, 2014.

13. ZHANG X.Z., SHEN Z.X., FU G. A meta-analysis of the effects of experimental warming on soil carbon and nitrogen dynamics on the Tibetan Plateau. Appl. Soil Ecol. 87, 32, 2015.

14. WU T.H., ZHAO L., LI R., WANG Q.X., XIE C.W., PANG Q.Q. Recent ground surface warming and its effects on permafrost on the central Qinghai-Tibet Plateau. Int. J. Climatol. 33, 920, 2013.

15. LUO C.Y., XU G.P., WANG Y.F., WANG S.P., LIN X.W., HU Y.G., ZHANG Z.H., CHANG X.F., DUAN J.C., SU A.L., ZHAO X.Q. Effects of grazing and experimental warming on DOC concentrations in the soil solution on the Qinghai-Tibet Plateau. Soil Biol. Biochem. 41, 2493, 2009.

16. WANG Z.Y., WU N., WANG B., LUO P., ZHANG Y.B., SUN G. Microbial communities of alpine meadow soil in the eastern Qinghai-Tibetan Plateau subjected to experimental warming and grazing. Chinese Journal of Applied Environmental Biology. 17 (2), 151, 2011.

17. JING X., WANG Y.H., CHUNG H.G., MI Z.R., WANG S.P., ZENG H., HE J.S. No temperature acclimation of soil extracellular enzymes to experimental warming in an alpine grassland ecosystem on the Tibetan Plateau. Biogeochemistry. 117 (1), 39, 2013.

18. KLEIN J.A., HARTE J., ZHAO X.Q. Experimental warming causes large and rapid species loss, dampened by simulated grazing, on the Tibetan Plateau. Ecol. Lett. 7, 1170, 2004.

19. KLEIN J.A., HARTE J., ZHAO X.Q. Dynamic and complex microclimate responses to warming and grazing manipulations. Global Change Biol. 11, 1440, 2005.

20. KLEIN J.A., HARTE J., ZHAO X.Q. Experimental warming, not grazing, decreases rangeland quality on the Tibetan. Ecol. Appl. 17, 541, 2007.

21. WANG S.P., DUAN J.C., XU G.P., WANG Y.F., ZHANG Z.H., RUI Y.C., LUO C.Y., XU B.R.B.Y., ZHU X.X., CHANG X.F., CUI X.Y., NIU H.S., ZHAO X.Q., WANG W.Y. Effects of warming and grazing on soil $\mathrm{N}$ availability, species composition, and ANPP in an alpine meadow. Ecology. 93 (11), 2365, 2012.

22. IPCC. Climate change 2013: The Physical Science Basis. NewYork: Cambridge University Press. 2013.

23. ZHAO X.Q. Alpine Meadow Ecosystem and Global Change (1st Ed.). Science Press: Beijing, China. 2009.

24. STEINAURE K., TILMAN D., WRAGG P.D., CESARZ S., COWLES J.M., PRITSCH K., REICH P.B., WEISSER W.W., EISENHAUER N. Plant diversity effects on soil microbial functions and enzymes are stronger than warming in a grassland experiment. Ecology. 96 (1), 99, 2015.

25. ZHAO L., LI Y.N., GU S., ZHAO X.Q., XU S.X., YU G.R. Carbon dioxide exchange between the atmosphere and an alpine shrubland meadow during the growing season on the Qinghai-Tibetan Plateau. J. Integr. Plant Biol. 47 (3), 27, 2005.

26. ZHAO X.Q., ZHOU X.M. Ecological basis of alpine meadow ecosystem management in Tibet: Haibei alpine meadow ecosystem research station. Ambio. 28, 642, 1999.

27. YI X.F., YANG Y.Q., ZHANG X.A., LI L.X., ZHAO L. No $\mathrm{C}_{4}$ plants found at the Haibei Alpine Meadow Ecosystem Research Station in Qinghai, China: evidence from stable carbon isotope studies. Acta Botanica Sinica. 45, 1291, 2003.

28. NORBY R.J., EDWARDS N.T., RIGGS J.S., ABNER C.H., WULLSCHLEGER S.D., GUNDERSON C.A. Temperaturecontrolled open-top chambers for global change research. Global Change Biol. 3 (3), 259, 1997.

29. BROOKES P.C., LANDMAN A., PRUDEN G.,
JENKINSON D.S. Chloroform fumigation chloroform fumigation and the release of soil nitrogen: a rapid direct extraction method to measure microbial biomass nitrogen in soil. Soil Biol. Biochem. 17 (6), 837, 1985.

30. VANCE E.D., BROOKES P.C., JENKINSON D.S. An extraction method for measuring soil microbial biomass $\mathrm{C}$. Soil Biol. Biochem. 19, 703, 1987.

31. LU R.K. Analysis method of Soil Agricultural Chemistry. Agricultural science and technology press: Beijing, China. 228, 2000 [In Chinese].

32. LI W.J., LI J.H., JOHANNES M.H.K., WANG G., JIA J.J., QIN Y.Y. Plant communities, soil carbon, and soil nitrogen properties in a successional gradient of sub-alpine meadows on the eastern Tibetan Plateau of China. Environ. Manage. 44, 755, 2009.

33. RINNAN R., MICHELSEN A., JONASSON S. Effects of litter addition and warming on soil carbon, nutrient pools and microbial communities in a subarctic heath ecosystem. Appl. Soil Ecol. 39, 271, 2008.

34. TIAN H.T., LU C.Q., YANG J., BANGER K., HUNTINZGER D.N., SCHWALM C.R., MICHALAK A.M., COOK R., CIAIS P., HAYES D., HUANG M.Y., ITO A., JAIN A., LEI H.M., MAO J.F., PAN S.F., POST W.M., PENG S.S., POULTER B., REN W., RICCIUTO D., SCHAEFER K., SHI X.Y., TAO B., WANG W.L., WEI Y.X., YANG Q.C., ZHANG B.W., ZENG N. Global patterns and controls of soil organic carbon dynamics as simulated by multiple terrestrial biosphere models: current status and future directions. Global Biogeochem. Cy. 29 (6), 775, 2015.

35. ZHOU H.K., ZHOU X.M., ZHAO X.Q. A preliminary study of the influence of simulated greenhouse effect on a Kobresia Humilis Meadow. Acta Phytoecologica Sinica. 24 (5), 547, 2000 [In Chinese].

36. COMELISSEN J.H.C., VAN BODEGOM, P.M., AERTS R., CALLAGHAN T.V., VAN LOGTESTIJN R.S.P., ALATALO J., CHAPIN F.S., GERDOL, R., GUDMUNDSSON J., GWYNN-JONES D., HARTLEY A.E., HIK D.S., HOFGAARD A., JÓNSDÓTTIR I.S., KARLSSON S., KLEIN J.A., LAUNDRE J., MAGNUSSON B., MICHELSEN A., MOLAU U., ONIPCHENKO V.G., QUESTED H.M., SANDVIK S.M., SCHMIDT I.K., SHAVER G.R., SOLHEIM B., SOUDZILOVSKAIA N.A., STENSTRÖM A., TOLVANEN A., TOTLAND Ø., WADA N., WELKER J.M., ZHAO, X.Q., TEAM, M.O.L. Global negative vegetation feedback to climate warming responses of leaf litter decomposition rates in cold biomes. Ecol. Lett. 10, 619, 2007.

37. LANGE M., EISENHAUER N., SIERRA C.A., BESSLER H., ENFELS C., GRIFFITHS R.I., MELLADO-VÁZQUEZ P.G., MALIK A.A., ROY J., SCHEU S., STEINBEISS S., THOMSON B.C., TRUMBORE S.E., GLEIXNER G. Plant diversity increases soil microbial activity and soil carbon storage. Nat. Commun. 6, 6707, 2015.

38. JIA X.H., ZHOU X.H., LUO Y.Q., XUE K., XUE X., XU X., YANG Y.H., WU L.Y., ZHOU J.R. Effects of substrate addition on soil respiratory carbon release under long-term warming and clipping in a tallgrass prairie. Plos One. 9 (12), e114203, 2014.

39. ALLISON S.D. Modeling adaptation of carbon use efficiency in microbial communities. Front. Microbiol. 5, 571, 2014.

40. SHEN Z.X., LI Y.L., FU G. Response of soil respiration on short-term experimental warming and precipitation pulses over the growing season in an alpine meadow on the North Tibet. Appl. Soil Ecol. 90, 35, 2015.

41. PENG F., YOU Q.G., XU M.H., GUO J., WANG T., XUE $\mathrm{X}$. Effects of warming and clipping on ecosystem carbon 
fluxes across two hydrologically contrasting years in an alpine meadow of the Qinghai-Tibet Plateau. Plos One. 9 (10), e109319, 2014.

42. XU M.H., PENG F., YOU Q.G., GUO J., TIAN, X.F., LIU

M., XUE X. Effects of warming and clipping on plant and soil properties of an alpine meadow in the Qinghai-Tibetan Plateau, China. J. Arid Land. 7 (2), 189, 2015.

43. WARDLE D.A., BARDGETT R.D., KLIRONOMOS
J.N., SETALA H., van der PUTTEN W.H., WALL D.H. Ecological linkages between aboveground and belowground biota. Science. 304, 1629, 2004.

44. ZECHMEISTER-BOLTENSTEM S., KEIBLINGER M.K., MOOSHAMMER M., PEÑUELAS J., RICHTER A., SARDANS J., WANEK W. The application of ecological stoichiometry to plant-microbial-soil organic matter transformations. Ecol. Monogr. 85 (2), 133, 2015. 